\title{
Performance, Carcass Characteristics, Cardio-Pulmonary Morphometry, Gut-Morphology, Fatty Acid Profile and Humoral Immunity of Commercial Broiler Birds Fed Diet Supplemented with Blended Fish Protein
}

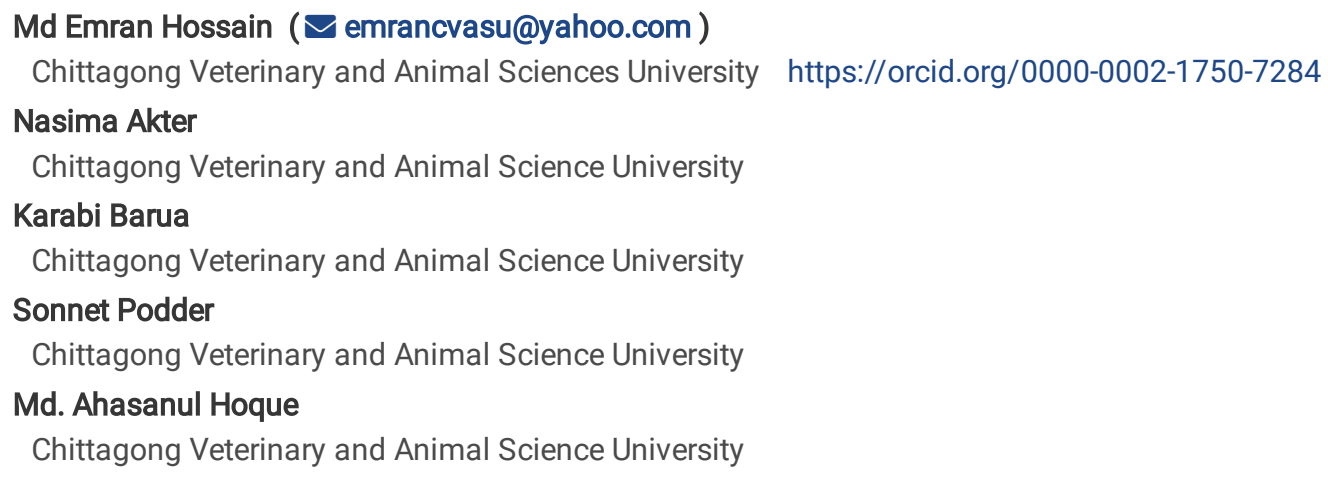

Keywords: Broiler, cardio-pulmonary morphometry, fatty acid profile, fish protein, performance

Posted Date: August 2nd, 2021

DOI: https://doi.org/10.21203/rs.3.rs-713134/v1

License: 두 (i) This work is licensed under a Creative Commons Attribution 4.0 International License. Read Full License 


\section{Abstract}

A 35-day trial was conducted to explore if different sources of dietary proteins at varying levels of metabolizable energy had any effect on the average daily feed intake (ADFI), average daily gain (ADG), feed efficiency (FE), carcass characteristics, cardio-pulmonary morphometry, gut morphology, profile of unsaturated fatty acid (UFA), saturated fatty acid (SFA), monounsaturated fatty acid (MUFA), polyunsaturated fatty acid (PUFA) and humoral immunity of the broiler birds. Total 288 Ross-308 day old male broiler birds were randomly distributed in four dietary treatment groups in a $2 \times 2$ factorial arrangement (Two different sources of proteins, i.e., plant and animal with two different levels of metabolizable energy, i.e., low and high). Each treatment had nine replicates containing eight birds per pen. Results indicated that, the supplementation of blended fish protein substantially increased $(p<0.001)$ the final body weight and decreased $(p<0.001)$ the ADFI at 1-14 d, $15-35 d$ and 1-35 $d$ compared with plant protein. The ADG increased at 1-14 $d(p<0.001), 15-35 d(p<0.05)$ and 1-35 $d(p<0.05)$ and the FE improved $(p<0.001)$ at 1-14 $d, 15-35 d$ and 1-35 d. Similarly, the high energy diet significantly increased $(p<0.001)$ the final body weight and decreased the ADFI at 1-14 $d(p<0.001), 15-35 d(p<0.05)$ and 1-35 $d(p<0.05)$ compared with low energy diet. The ADG increased $(p<0.001)$ and the FE improved at 1-14 d, 15-35 d and 1-35 d. The animal protein increased the thigh weight $(p<0.01)$, the neck weight $(p<0.05)$ and the ratio $(p<0.001)$ of $\sum$ UFA: $\sum$ SFA and $\sum$ PUFA: $\sum$ MUFA in the breast muscles of the broiler birds. The GLM identified no interaction effect ( $p>0.05$ ) of energy and protein on the $A D F I, A D G, F E$, cardio-pulmonary morphometry and humoral immunity of the broiler birds against Newcastle and Infectious Bronchitis diseases. The RV:TV remained within standard range indicating no symptoms of cardiac dysfunctions. It was concluded that the fishmeal supplemented high energy diet improved weight gain, feed efficiency and meat quality of broiler by increasing $\sum \omega-3$ and $\sum \omega-7$ fatty acids as well as the ratio of $\sum \omega-3: \sum \omega-6, \sum$ UFA: $\sum$ SFA and $\sum$ PUFA: $\sum$ MUFA in the breast muscles of the broiler birds.

\section{Introduction}

Protein plays an important role in all the vital processes of the animal body (Beski et al., 2015). It helps synthesis of body tissues for development, maintenance, and remodeling of essential organs of the rapidly growing broiler birds (Mills et al., 2019). Commercial broiler chickens have very high dietary protein requirement (Gous, 2007). Hence, recognizable proof of the ideal protein sources for broilers is important for enhancing their performance. The vegetable and animal proteins are the two most unique sources of protein in poultry diet. Plant proteins are the most widely used protein sources for broiler chicken that are normally less expensive than animal proteins. However, there are many limitations to their incorporation in poultry diet due to content of anti-nutritional factors (ANFs). The most commonly used plant protein source in broiler diet is soybean meal (SBM). The SBM has the highest feeding value among all the plant protein sources in terms of protein content, digestibility and amino acid blends required to meet the nutrient demands for the birds of almost all species (Cromwell, 1999, 2008). Despite potential virtues, the SBM has a high alliance of ANFs, i.e., haemagglutinins, phytic acid, goitrogens, saponins, tannins, gossypols, oxalates, lectins, trypsin and amylase inhibitors which decline the nutritive worth and limit its incorporation in the diet of the growing broiler (Yasothai, 2016).

The animal proteins, on the other hand, offer an elevated array of essential amino acids, fat soluble vitamins, vitamin $B_{12}$, calcium, phosphorus, and sensible measures of different micro-minerals with very high degrees of accessibility and lack of major ANFs, i.e., trypsin inhibitor, gossypol, saponin, and phytic acid (Cho and Kim, 2011; Hossain et al., 2013). Feeding unique animal protein sources to the chicks, particularly at an earlier stage, may enhance early gut development, improved physiological parameter, increased muscle enlargement and insusceptibility of the birds to different infectious diseases. Thus, the virtues for supplementation of the immunologically dynamic blends of animal proteins are the primary focal point for the performance, gut wellbeing and immunity of the living birds.

Fish meal is a natural, balanced animal protein supplement that is high in protein and energy. High biological value (Sifri, 1995), contents of lysine, methionine, arginine, choline, biotin, vitamin A, D, E, K, calcium, phosphorus and vitamin $B_{12}($ Scanes, 2010) make the feeding value (Pike, 1999; Kolacz et al., 2003; Takahashi et al., 2004; Leeson and Summers, 2009) of fishmeal unquestionable for broiler. Fishmeal has been considered as a potential feed ingredient to supplement deficiencies of essential amino acids in poultry rations (Sifri, 1995; Pike, 1999). Several researchers have come to the conclusion that fishmeal contains unidentified growth factors responsible for palatability of feedstuffs and improvement in performance of the broiler chicken (Barlow and Windsor, 1984; El Boushy and van der Poel, 2000). Despite many advantages, higher cost relative to plant proteins and presence of trimethylamine in fish meal responsible for fishy smell in broiler meat limit their inclusion in poultry diet. Net cost-benefit analysis associated with incorporation of blended fish proteins at varying dietary energy levels and its subsequent effects on performance, carcass characteristics, cardio-morphometry, gut-morphology, fatty acid profile and humoral immunity in broiler birds are scant. We therefore, aimed to focus light on these grey areas through this study.

\section{Materials And Methods}

\section{Study design, animals and housing}


The experiment was conducted in a two way $2^{2}$ factorial arrangements (Two different sources of proteins, i.e., plant and animal with two levels of Metabolizable energy, e.g., low and high). Total 256 Ross-308 day old male broiler chicks were randomly distributed into eight dietary treatment groups with four replicates having 8 birds per pen (Table 1). The chicks were purchased from Nahar Agro Ltd., Chattogram, Bangladesh. All chicks were examined for male, grade A, uniform size without abnormalities. Floor space for each bird was 0.17 square feet in brooding box and 1 square feet in the cage. The birds were exposed to continuous lighting for the 1 st three days followed by $1-4$ hours of dark for the remaining 1-4 weeks. The chicks were brooded at a temperature of $95^{\circ} \mathrm{F}, 90^{\circ} \mathrm{F}, 85^{\circ} \mathrm{F}$ and $80^{\circ} \mathrm{F}$ for the $1 \mathrm{st}$, $2 \mathrm{nd}$, 3rd and 4 th weeks, respectively with the help of incandescent bulbs. Room temperature and humidity were measured by using wall mounted indoor analog thermo-hygrometer. Before arrival of the chicks, the shed was thoroughly cleaned and washed by using tap water with caustic soda. For disinfection, phenyl solution ( $1 \% \mathrm{v} / \mathrm{v})$ was sprayed on the floor, corners and ceiling. Following spray, cleaning was done by using brush and clean water. Brooding boxes, rearing cages and pens were cleaned in the same manner. After cleaning and disinfection, the house was left empty one week for proper drying. After drying, all doors and windows were closed. The room was fumigated with single strength fumigant (Adding $40 \mathrm{ml}$ formalin to $20 \mathrm{~g} \mathrm{KMnO}_{4}$ for 100 cubic feet area) and sealed for 24 hours. On the next day, lime was spread on the floor and around the shed. Footbath containing potassium permanganate $(1 \% \mathrm{w} / \mathrm{v})$ was kept at the entrance of the poultry shed and changed regularly. Feeders and drinkers were cleaned and washed with Timsen ${ }^{\circledR}$ solution $(0.3 \% \mathrm{v} / \mathrm{v})$ daily. All birds were vaccinated against Newcastle and Gumboro disease with both the primary and booster doses. After each vaccination, lemon juice as a vitamin-C supplement was supplied through drinking water to overcome the effect of stress due to vaccination.

Table 1

Design of the experiment

\begin{tabular}{|lllll|}
\hline \multicolumn{2}{|l}{ Dietary treatments } & No. of treatments & No. of replicates & No. of day old male birds \\
\hline Protein & Energy & & 9 & \\
\hline 0 (Plant protein) & 1 (Low energy) & 1 & 9 & $9 \times 8=72$ \\
\hline 0 (Plant protein) & 2 (High energy) & 1 & 9 & $9 \times 8=72$ \\
\hline 1 (Fish protein) & 1 (Low energy) & 1 & 9 & $9 \times 8=72$ \\
\hline 1 (Fish protein) & 2 (High energy) & 1 & 36 & $4 \times 8=72$ \\
\hline Total & & 4 & & $4 \times 8=288$ \\
\hline
\end{tabular}


Table 2

Starter $(1-14 \mathrm{~d})$ and finisher (15-35 d) rations for the experimental broiler birds

\begin{tabular}{|c|c|c|c|c|c|c|c|c|}
\hline \multirow[t]{3}{*}{ Ingredients } & \multicolumn{8}{|c|}{ Ration for the experimental birds ${ }^{1}$} \\
\hline & \multicolumn{4}{|c|}{ Starter (1-14 d) } & \multicolumn{4}{|c|}{ Finisher (15-35 d) } \\
\hline & LEPP & HEPP & LEAP & HEAP & LEPP & HEPP & LEAP & HEAP \\
\hline Maize & 54.19 & 53.49 & 54.39 & 54.09 & 57.00 & 57.75 & 57.66 & 57.75 \\
\hline Rice polish & 1.00 & 0.50 & 1.70 & 1.00 & 2.00 & 1.00 & 2.30 & 1.50 \\
\hline DDGS & 0.30 & 1.00 & 0.50 & 0.90 & 0.30 & 0.30 & 0.30 & 0.30 \\
\hline Soybean oil & 0.75 & 2.00 & 0.50 & 1.80 & 2.00 & 3.00 & 1.80 & 3.00 \\
\hline Soybean meal & 40.45 & 40.20 & 36.00 & 36.00 & 35.33 & 35.30 & 31.00 & 31.00 \\
\hline Fish meal ${ }^{2}$ & - & - & 3.50 & 3.50 & - & - & 3.50 & 3.50 \\
\hline Lime stone & 1.60 & 1.20 & 1.70 & 1.10 & 1.60 & 1.10 & 1.60 & 1.30 \\
\hline Dicalcium phosphate & 0.90 & 0.80 & 0.90 & 0.80 & 1.00 & 0.80 & 1.00 & 0.90 \\
\hline L-Lysine & 0.15 & 0.15 & 0.15 & 0.15 & 0.13 & 0.12 & 0.15 & 0.12 \\
\hline DL-Methionine & 0.20 & 0.20 & 0.20 & 0.20 & 0.18 & 0.17 & 0.18 & 0.17 \\
\hline Vitamin premix ${ }^{3}$ & 0.25 & 0.25 & 0.25 & 0.25 & 0.25 & 0.25 & 0.25 & 0.25 \\
\hline Feedzyme ${ }^{4}$ & 0.02 & 0.02 & 0.02 & 0.02 & 0.02 & 0.02 & 0.02 & 0.02 \\
\hline Common salt & 0.20 & 0.20 & 0.20 & 0.20 & 0.20 & 0.20 & 0.25 & 0.20 \\
\hline Total & 100.00 & 100.00 & 100.00 & 100.00 & 100.00 & 100.00 & 100.00 & 100.00 \\
\hline \multicolumn{9}{|c|}{ Calculated values (\% or otherwise stated) } \\
\hline $\mathrm{ME}(\mathrm{kcal} / \mathrm{kg})^{5}$ & 2909.35 & 2997.50 & 2903.53 & 3000.74 & 3015.12 & 3098.82 & 3014.05 & 3100.50 \\
\hline Crude protein & 23.01 & 22.99 & 23.05 & 23.06 & 21.07 & 21.00 & 21.09 & 21.01 \\
\hline Crude fibre & 3.61 & 3.61 & 3.57 & 3.48 & 3.44 & 3.43 & 3.37 & 3.28 \\
\hline Ether extract & 3.30 & 3.30 & 4.52 & 3.48 & 4.71 & 4.64 & 5.51 & 4.81 \\
\hline Calcium & 1.02 & 1.02 & 0.85 & 1.22 & 0.97 & 1.03 & 0.89 & 1.19 \\
\hline Phosphorus & 0.70 & 0.70 & 0.68 & 0.74 & 0.71 & 0.71 & 0.67 & 0.74 \\
\hline Available phosphorus & 0.40 & 0.40 & 0.38 & 0.45 & 0.43 & 0.42 & 0.38 & 0.46 \\
\hline Sodium & 0.01 & 0.01 & 0.01 & 0.04 & 0.04 & 0.01 & 0.01 & 0.04 \\
\hline Potassium & 1.01 & 1.01 & 1.00 & 0.93 & 0.92 & 0.90 & 0.88 & 0.81 \\
\hline Magnesium & 0.14 & 0.14 & 0.14 & 0.14 & 0.14 & 0.14 & 0.13 & 0.13 \\
\hline \multicolumn{9}{|c|}{${ }^{1}$ LEPP $=$ Low energy plant protein, HEPP = High energy plant protein, LEAP = Low energy animal protein, HEAP $=$ High energy animal protein } \\
\hline \multicolumn{9}{|c|}{ 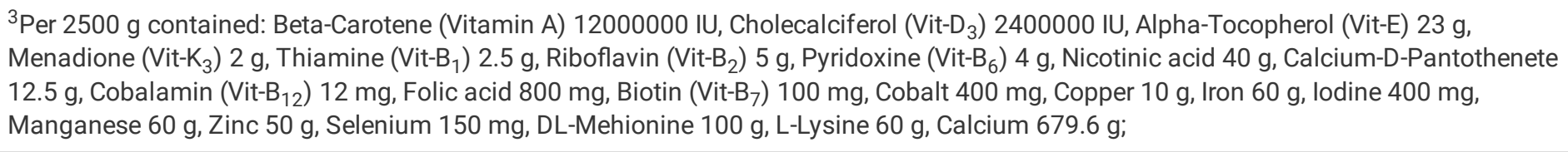 } \\
\hline \multicolumn{9}{|c|}{$\begin{array}{l}\text { 4Per } 100 \text { g contained: Cellulase } 20000 \text { IU, Xylanase } 200000 \text { IU, Protease } 20 \text { IU, Amylase } 40000 \text { IU, Phytase } 20 \text { IU, Pectinase } 1400 \text { IU, } \\
\text { Invertase } 400 \text { IU, Hemicellulose } 500 \text { IU, Lipase } 20 \text { IU, a-Galactosidase } 100 \text { IU; }\end{array}$} \\
\hline \multicolumn{9}{|c|}{${ }^{5}$ Metabolizable energy $(\mathrm{kcal} / \mathrm{kg})$; } \\
\hline \multicolumn{9}{|c|}{${ }^{6}$ As per standard procedure (AOAC, 2019); } \\
\hline${ }^{7} \mathrm{App}$ arent gross enerc & $\mathrm{kg})$. & & & & & & & \\
\hline
\end{tabular}




\begin{tabular}{|c|c|c|c|c|c|c|c|c|}
\hline \multirow[t]{3}{*}{ Ingredients } & \multicolumn{8}{|c|}{ Ration for the experimental birds ${ }^{1}$} \\
\hline & \multicolumn{4}{|c|}{ Starter (1-14 d) } & \multicolumn{4}{|c|}{ Finisher (15-35 d) } \\
\hline & LEPP & HEPP & LEAP & HEAP & LEPP & HEPP & LEAP & HEAP \\
\hline Manganese (mg/kg) & 82.68 & 82.68 & 81.63 & 83.16 & 81.75 & 82.68 & 80.59 & 82.35 \\
\hline Zinc (mg/kg) & 90.25 & 90.25 & 87.58 & 95.81 & 92.05 & 93.55 & 88.06 & 96.90 \\
\hline Copper (mg/kg) & 18.06 & 18.06 & 18.00 & 18.11 & 18.07 & 17.32 & 17.25 & 17.36 \\
\hline Iron (mg/kg) & 162.78 & 162.78 & 162.35 & 176.42 & 176.06 & 154.59 & 153.73 & 167.98 \\
\hline Lysine & 1.43 & 1.43 & 1.43 & 1.41 & 1.41 & 1.28 & 1.27 & 1.28 \\
\hline Leucine & 1.97 & 1.97 & 1.98 & 1.95 & 1.95 & 1.83 & 1.83 & 1.80 \\
\hline Iso-leucine & 1.01 & 1.01 & 1.01 & 0.98 & 0.98 & 0.92 & 0.91 & 0.89 \\
\hline Valine & 1.11 & 1.11 & 1.10 & 1.10 & 1.10 & 1.01 & 1.01 & 1.01 \\
\hline Threonine & 1.30 & 1.30 & 1.30 & 1.25 & 1.25 & 1.17 & 1.17 & 1.12 \\
\hline Methionine & 0.56 & 0.56 & 0.56 & 0.56 & 0.56 & 0.51 & 0.51 & 0.52 \\
\hline Tryptophan & 0.29 & 0.29 & 0.29 & 0.28 & 0.28 & 0.26 & 0.26 & 0.25 \\
\hline Phenylalanine & 1.16 & 1.16 & 1.16 & 1.13 & 1.13 & 1.06 & 1.05 & 1.03 \\
\hline Cystine + methionine & 0.75 & 0.75 & 0.75 & 0.75 & 0.75 & 0.70 & 0.70 & 0.70 \\
\hline \multicolumn{9}{|c|}{${ }^{1}$ LEPP $=$ Low energy plant protein, HEPP = High energy plant protein, LEAP = Low energy animal protein, HEAP = High energy animal protein } \\
\hline \multicolumn{9}{|c|}{ 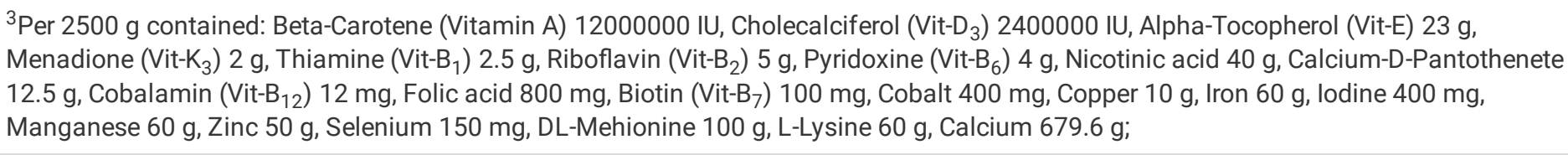 } \\
\hline \multicolumn{9}{|c|}{$\begin{array}{l}{ }^{4} \text { Per } 100 \text { g contained: Cellulase } 20000 \text { IU, Xylanase } 200000 \text { IU, Protease } 20 \text { IU, Amylase } 40000 \text { IU, Phytase } 20 \text { IU, Pectinase } 1400 \text { IU, } \\
\text { Invertase } 400 \text { IU, Hemicellulose } 500 \text { IU, Lipase } 20 \text { IU, a-Galactosidase } 100 \text { IU; }\end{array}$} \\
\hline \multicolumn{9}{|c|}{${ }^{5}$ Metabolizable energy $(\mathrm{kcal} / \mathrm{kg})$} \\
\hline \multicolumn{9}{|c|}{${ }^{6}$ As per standard procedure (AOAC, 2019); } \\
\hline
\end{tabular}




\begin{tabular}{|c|c|c|c|c|c|c|c|c|}
\hline \multirow[t]{3}{*}{ Ingredients } & \multicolumn{8}{|c|}{ Ration for the experimental birds ${ }^{1}$} \\
\hline & \multicolumn{4}{|c|}{ Starter $(1-14 d)$} & \multicolumn{4}{|c|}{ Finisher (15-35 d) } \\
\hline & LEPP & HEPP & LEAP & HEAP & LEPP & HEPP & LEAP & HEAP \\
\hline \multicolumn{9}{|l|}{ Analyzed value $^{6}$} \\
\hline $\mathrm{AGE}^{7}(\mathrm{kcal} / \mathrm{kg})$ & 3651.13 & 3507.65 & 3579.39 & 3543.52 & 3757.06 & 3609.3 & 3683.18 & 3646.24 \\
\hline Crude protein & 22.55 & 22.76 & 22.36 & 22.14 & 20.44 & 20.79 & 20.25 & 20.59 \\
\hline Crude fibre & 3.54 & 3.57 & 3.46 & 3.34 & 3.34 & 3.40 & 3.24 & 3.21 \\
\hline Ether extract & 3.23 & 3.27 & 4.38 & 3.34 & 4.57 & 4.59 & 5.29 & 4.71 \\
\hline Calcium & 1.00 & 1.01 & 0.87 & 1.17 & 0.94 & 1.02 & 0.86 & 1.17 \\
\hline Phosphorus & 0.69 & 0.69 & 0.66 & 0.71 & 0.69 & 0.70 & 0.64 & 0.73 \\
\hline \multicolumn{9}{|c|}{${ }^{1}$ LEPP $=$ Low energy plant protein, HEPP = High energy plant protein, LEAP = Low energy animal protein, HEAP = High energy animal protei } \\
\hline \multicolumn{9}{|c|}{ 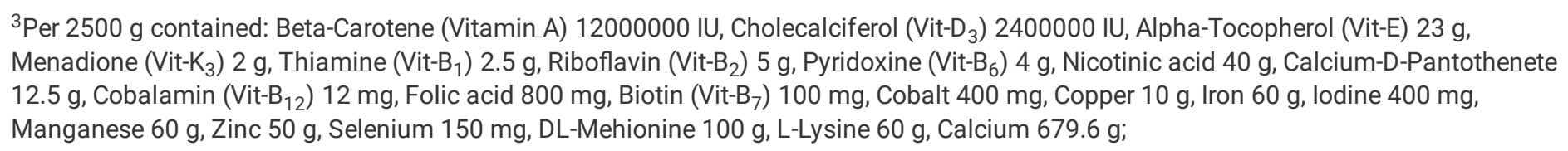 } \\
\hline \multicolumn{9}{|c|}{$\begin{array}{l}\text { 4Per } 100 \text { g contained: Cellulase } 20000 \text { IU, Xylanase } 200000 \text { IU, Protease } 20 \text { IU, Amylase } 40000 \text { IU, Phytase } 20 \text { IU, Pectinase } 1400 \text { IU, } \\
\text { Invertase } 400 \text { IU, Hemicellulose } 500 \text { IU, Lipase } 20 \text { IU, a-Galactosidase } 100 \text { IU; }\end{array}$} \\
\hline \multicolumn{9}{|c|}{${ }^{5}$ Metabolizable energy (kcal/kg); } \\
\hline \multicolumn{9}{|c|}{${ }^{6}$ As per standard procedure (AOAC, 2019); } \\
\hline${ }^{7}$ Apparent gros & $\mathrm{kg})$. & & & & & & & \\
\hline
\end{tabular}


Table 3

Initial live weight (ILW, g/bird), final live weight (FLW, g/bird), average daily feed intake (ADFl, g/bird/d), average daily gain (ADG, g/bird/d) and feed efficiency (FE, ADFI/ADG) of the broiler birds fed diet supplemented with two different sources of dietary protein and two different levels

\begin{tabular}{|c|c|c|c|c|c|c|c|c|c|c|c|}
\hline \multirow{3}{*}{$\begin{array}{l}\text { Treatment } \\
\text { factors }^{1}\end{array}$} & \multirow{3}{*}{$\begin{array}{l}\text { ILW } \\
\text { (g/bird) }\end{array}$} & \multirow{3}{*}{$\begin{array}{l}\text { FLW } \\
\text { (g/bird) }\end{array}$} & \multicolumn{9}{|c|}{ Performance parameter } \\
\hline & & & \multicolumn{3}{|c|}{ ADFI (g/bird/d) } & \multicolumn{3}{|c|}{ ADG (g/bird/d) } & \multicolumn{3}{|l|}{ FE } \\
\hline & & & $\begin{array}{l}1-14 \\
d\end{array}$ & $\begin{array}{l}\text { 15-35 } \\
d\end{array}$ & $d^{1-35}$ & $\begin{array}{l}1-14 \\
d\end{array}$ & $\begin{array}{l}15-35 \\
d\end{array}$ & ${ }_{d}^{1-35}$ & $\begin{array}{l}1-14 \\
d\end{array}$ & $\begin{array}{l}\text { 15-35 } \\
d\end{array}$ & $1-35 d$ \\
\hline \multicolumn{12}{|l|}{ Protein } \\
\hline 0 & 40.91 & 1982.95 & 33.65 & 116.52 & 83.37 & 30.79 & 91.99 & 55.20 & 1.10 & 1.27 & 1.51 \\
\hline 1 & 41.97 & 2424.87 & 32.42 & 103.26 & 74.92 & 32.63 & 93.93 & 56.36 & 1.00 & 1.10 & 1.39 \\
\hline \multicolumn{12}{|l|}{ Energy } \\
\hline 1 & 40.89 & 2153.03 & 33.97 & 111.97 & 80.77 & 30.57 & 90.57 & 54.34 & 1.12 & 1.24 & 1.49 \\
\hline 2 & 42.00 & 2254.79 & 32.10 & 107.81 & 77.53 & 32.86 & 95.35 & 57.21 & 0.98 & 1.13 & 1.36 \\
\hline \multicolumn{12}{|l|}{ Protein $\times$ Energy } \\
\hline Protein $_{0} \times$ Energy $_{1}$ & 40.90 & 1925.58 & 34.52 & 118.45 & 84.88 & 29.50 & 89.31 & 53.59 & 1.17 & 1.32 & 1.58 \\
\hline Protein $_{0} \times$ Energy $_{2}$ & 41.73 & 2040.32 & 32.78 & 114.58 & 81.86 & 32.08 & 94.67 & 56.80 & 1.02 & 1.21 & 1.44 \\
\hline Protein $_{1} \times$ Energy $_{1}$ & 41.68 & 2380.47 & 33.41 & 105.49 & 76.65 & 31.63 & 91.83 & 55.10 & 1.06 & 1.15 & 1.39 \\
\hline Protein $_{1} \times$ Energy $_{2}$ & 42.27 & 2469.26 & 31.42 & 101.04 & 73.19 & 33.63 & 96.02 & 57.61 & 0.94 & 1.05 & 1.37 \\
\hline SEM $^{2}$ & 0.80 & 40.02 & 0.23 & 1.63 & 1.04 & 0.32 & 0.70 & 0.42 & 0.02 & 0.02 & 0.02 \\
\hline \multicolumn{12}{|l|}{ Significance ${ }^{3}$} \\
\hline Protein & NS & $\star \star \star$ & $\star \star \star$ & $\star \star \star$ & $\star \star \star$ & $\star \star \star$ & * & * & $\star \star \star *$ & $\star \star *$ & $\star \star \star$ \\
\hline Energy & NS & $\star \star \star$ & $\star \star \star$ & * & * & $\star \star \star$ & $\star \star \star$ & $\star \star \star$ & $\star \star \star$ & $\star \star \star$ & $\star \star \star$ \\
\hline Protein $\times$ Energy & NS & NS & NS & NS & NS & NS & NS & NS & NS & NS & NS \\
\hline \multicolumn{12}{|c|}{${ }^{1}$ Protein, 0 = Low, 1 = High, Energy, 1 = Low, 2 = High; } \\
\hline \multicolumn{12}{|c|}{${ }^{2}$ SEM = Standard error of the means; } \\
\hline \multicolumn{12}{|c|}{${ }^{3} N S=$ Non-significant $(p>0.05), *=$ Significant $(p<0.05), * * *=$ Significant $(p<0.001)$} \\
\hline
\end{tabular}

\section{Experimental diets}

Feed ingredients were purchased from Pahartali market, Chattogram, Bangladesh. During purchase, cleanliness and date of expiry was checked. Dry mash was provided to the birds throughout the whole experimental period. Four different types of rations were formulated. Each ration was two different types i.e., starter ( 0 to 14 days) and finisher (15 to 28 days). All rations were iso-caloric and iso-nitrogenous. Feed was prepared manually and supplied ad-libitum to the birds on round small feeder and waterer for $0-7$ days. After 7 th day, these feeders and waterers were replaced by medium linear feeders $(2.21 \mathrm{ft} X 0.25 \mathrm{ft})$ and round waterers. At 15th day, large linear feeder $(3.5 \mathrm{ft} X 0.38 \mathrm{ft})$ and round waterers (3 liter capacity) were provided for feeding and drinking of the birds.

\section{Chemical analyses}

From each treatment, $100 \mathrm{~g}$ of prepared mash feed was taken and preserved in an air tight bag to carry out the chemical analysis. Chemical analyses of the feeds were carried out in triplicate for dry matter (DM), crude protein (CP), crude fiber (CF), nitrogen free extracts (NFE), ether extract (EE), total ash (TA), calcium and phosphorus (P) in the animal nutrition postgraduate laboratory, Chattogram Veterinary and Animal Sciences University, Chattogram as per standard procedure (AOAC, 2019). Moisture was estimated by Hot air oven (SLN-115, Pol-Eko-Aparatus SPJ, Poland). CP was estimated by micro Kjeldhal apparatus (Kjeldhal digestion unit SBS800, Kjeldhal distillation unit D1000, FoodAlyt, Germany). CF was estimated by using Ankom Fiber Analyzer (Fiberbag System-6, Gerhardt, Germany). EE was estimated by using Soxtec (RS- 
232, SER-148, Velp Scientifica, 155 Keyland Court, Bohemia, NY 11716 - US). TA was estimated by the muffle furnace (HYSC, Non Yong Scientific Equipment Company Ltd., 874-1 Wolgye 4-dong, Nowon-gu, Seoul, Korea). Gross energy (GE) of mixed diets was estimated by using the bomb calorimeter (Parr 6200 Calorimeter, Parr Instruments Co., USA).

\section{Performance parameter}

Mortality was recorded as occurred, while average daily feed intake (ADFI), average daily gain (ADG) and feed efficiency (FE) were recorded at fortnightly intervals. Carcass characteristics, hematological and biochemical parameters were recorded at 5th week. Weight gain was calculated by deducting initial body weight from the final body weight of the birds. Feed intake was calculated by deducting leftover from the total feeds supplied to the birds. The FE was calculated dividing feed intake by weight gain.

\section{Carcass characteristics}

At day 35, three birds from each replicate were randomly selected and killed by severing the jugular vein and carotid artery. Once a bird was adequately bled out, it was scalded and feather was removed. After defeathering, the birds were eviscerated and the head and feet were removed as per standard technique (Jones, 1984). During evisceration process, abdominal fat, lung, liver, kidney, spleen, gizzard and proventriculus were excised separately and weighed. Dressed birds were weighed to obtain a dressed carcass weight.

\section{Cardio-pulmonary morphometry}

The heart was isolated from the carcass immediate after slaughter. The data of heart weight, right ventricular weight, left ventricular weight, right ventricular diameter, left ventricular diameter, right ventricular thickness and left ventricular thickness were measured thereafter by using slide caliper (Wiika Vernier Caliper, 150 mm, WA-VC1150) and digital screw gauge (Mitutoyo, Quickmini, Mitutoyo corporation, Japan). The diameter of left and right ventricles were measured perpendicular to the long axis, at the maximum measureable dimensions and mean values were calculated.

\section{Gut morphology}

At day-30, two birds from each of 36 replicates were randomly selected for slaughter. The gastrointestinal tract was removed and separated into the three intestinal segments, i.e., duodenum, jejunum and ileum. The length, weight and diameter of duodenum was taken distally from the gizzard to the end of the pancreatic loop, the jejunum was taken distally from the pancreatic loop to Meckel's diverticulum, and the ileum was taken from the Meckel's diverticulum to the ileo-caecal junction. All measurements were triplicate and averaged later on.

\section{Fatty acid profile}

Lipids were extracted from the breast muscles (Pectoralis major and pectoralis minor) of the slaughtered birds by using a modified method (Folch et al., 1957). Fatty acid methyl esters were extracted by the gas chromatography using KOH/methanol. The Gas Chromatograph (Nexis, GC-2030, Shimadzu, Japan) was equipped with a robotic auto sampler (AOC 6000, Shimadzu, Japan), a hydrogen flame ionization detector (FID) and a quartz capillary chromatographic column (SH-Rt-2560; $100 \mathrm{~m} \times 0.25 \mathrm{~mm} \times 0.20 \mu \mathrm{m}$; Temperature range - 20 to $250^{\circ} \mathrm{C}$; Cat.\# 22736311-01; Serial \# 4, USA). The FID was set at $270^{\circ} \mathrm{C}$. Nitrogen was used as make up gas with a flow rate of $24.0 \mathrm{ml} / \mathrm{min}, \mathrm{FID} \mathrm{H}_{2}$ flow 32 $\mathrm{ml} / \mathrm{min}$, FID air flow $200 \mathrm{ml} / \mathrm{min}$ and split ratio $1: 10$. The column was set at $240^{\circ} \mathrm{C}$ with a primary pressure of $534.9 \mathrm{kPa}$, flow rate $1.2 \mathrm{ml} / \mathrm{min}$ and linear velocity $22.5 \mathrm{~cm} / \mathrm{s}$ constant for $60 \mathrm{~min}$. The fatty acids were identified by comparing the area of the peaks of the sample with that of known standards (SigmaAldrich, St. Louis, USA).

\section{Humoral immune response}

All chicks were vaccinated against Newcastle Disease virus (NDV) and Infectious Bursal Disease (IBD) virus. Blood samples were collected 7 days after each immunization, kept till clotting, and then, centrifuged at $3,000 \mathrm{~g}$ for $15 \mathrm{~min}$, and the sera samples were stored at $-80^{\circ} \mathrm{C}$ until determination of antibody titers. Serum antibody titers were determined by means of the hemagglutination inhibition (HI) test and ELISA for NDV and IBD respectively using ELISA test kit according to manufacturer instructions listed in the ELISA Kit (Symbiotic-USA).

\section{Statistical analysis}

Data were compiled and tested for outliers and multicollinearity by inter quartile range test and variance inflation factors. Normality of the response variables were checked by using normal probability plot and equality of variances was tested by Shapiro Wilk test. Data were analyzed for generalized linear model by using Stata 14.1 SE (Stata Corp LP, College Station, Texas, USA) considering ILW, FLW, ADFI, ADG, FE, carcass characteristics, cardio-pulmonary morphometry, gut-morphology, fatty acid profile and humoral immunity parameter as the outcome variable and the sources of protein as well as the levels of metabolizable energy as the treatment factor. Means showing significant differences were compared by Duncan's New Multiple Range Test (Duncan, 1955). Statistical significance was accepted at $p<0.05$ for the Fisher's F-tests. The following statistical model was used: 


\begin{tabular}{|c|c|c|}
\hline$Y_{\mathrm{ijk}}$ & $=$ & $\mu+a_{i}+\beta_{j}+(a \beta)_{i j}+\varepsilon_{i j k}$ \\
\hline \multicolumn{3}{|c|}{ Where, } \\
\hline$\mu$ & $=$ & The intercept of the regression model; \\
\hline$a_{i}$ & $=$ & The fixed effect of the ' $\mathrm{i}$ 'th' level of the factor ' $a$ ' (Sources of protein) on the value observed in $\mathrm{Y}_{\mathrm{ijk}}(\mathrm{i}=$ plant, animal); \\
\hline$\beta_{\mathrm{j}}$ & $=$ & The fixed effect of the ' $\mathrm{j}$ th' level of the factor ' $\beta$ ' (Level of energy) on the value observed in $Y_{i j k}(j=l o w, ~ h i g h) ;$ \\
\hline$(\mathrm{a} \beta)_{\mathrm{ij}}$ & $=$ & The interaction effect of the of the ' $\mathrm{i}$ 'th' level of the factor ' $a$ ' and the ' $\mathrm{j}$ 'th' level of the factor ' $\beta$ '; \\
\hline$Y_{i j k}$ & $=$ & $\begin{array}{l}\text { The observed effects of the variable under study at the ' } i \text { th' level of the factor ' } a \text { ' and the ' } j \text { th' level of the factor ' } \beta \text { ' for the ' } k \text { th' } \\
\text { repetition of measurements; }\end{array}$ \\
\hline$\varepsilon_{\mathrm{ijk}}$ & $=$ & $\begin{array}{l}\text { The random sampling error due to ' } \mathrm{i} \text { th' level of the factor ' } a \text { ' and ' } \mathrm{j} \text { 'th' level of the factor ' } \beta \text { ' at the ' } k{ }^{\text {th' }} \text { repetition of } \\
\text { measurements. }\end{array}$ \\
\hline
\end{tabular}

\section{Results}

\section{Performance}

Supplementation of blended fish protein substantially increased $(p<0.001)$ the final body weight and decreased ( $p<0.001)$ the ADFI at $1-14$ $d, 15-35 d$ and 1-35 d compared with plant protein. The ADG increased at 1-14 d ( $<<0.001), 15-35 d(p<0.05)$ and 1-35 d ( $<<0.05)$ and the FE improved $(p<0.001)$ at $1-14 d, 15-35 d$ and $1-35 d$. Similarly, the high energy diet significantly increased ( $p<0.001)$ the final body weight and decreased the ADFI at 1-14 d ( $<<0.001), 15-35 d(p<0.05)$ and 1-35 d $(p<0.05)$ compared with low energy diet. The ADG increased $(p<0.001)$ and the FE improved at 1-14 d, 15-35 d, and 1-35 d. The sources of dietary protein and the levels of metabolizable energy had no interaction effect ( $p>0.05)$ on the $A D F I, A D G$, and FE.

\section{Carcass characteristics}

Supplementation of animal protein increased the thigh weight $(p<0.01)$ and the neck weight $(p<0.05)$. The sources of dietary energy did not influence $(p<0.05)$ the carcass characteristics. The sources of dietary protein and the levels of metabolizable energy had no interaction effect $(p>0.05)$ on the carcass characteristics of the broiler birds (Table 4). 
Table 4

Carcass characteristics of the broilers fed diet supplemented with two sources of dietary protein and two different levels of metabolizable energy slaughtered at 35th day

\begin{tabular}{|c|c|c|c|c|c|c|c|c|c|c|c|c|c|}
\hline \multirow[t]{2}{*}{ Treatment factors ${ }^{1}$} & \multicolumn{13}{|c|}{ Relative weight of the carcass components as $\%$ live weight } \\
\hline & $\mathrm{DP}^{2}$ & $\mathrm{BRW}^{3}$ & $\mathrm{BKW}^{4}$ & TW5 & $\mathrm{DW}^{6}$ & $\mathrm{sW}^{7}$ & $\mathrm{HW}^{8}$ & NW9 & $\mathbf{W W}^{10}$ & $\mathrm{LW}^{11}$ & $\mathrm{GW}^{12}$ & $\mathrm{PW}^{13}$ & AFW $^{14}$ \\
\hline \multicolumn{14}{|l|}{ Protein } \\
\hline 0 & 64.5 & 21.7 & 13.2 & 10.0 & 9.1 & 4.5 & 2.4 & 2.4 & 7.2 & 2.1 & 0.5 & 2.8 & 1.0 \\
\hline 1 & 66.7 & 20.7 & 14.5 & 11.0 & 10.2 & 5.1 & 2.5 & 2.5 & 7.5 & 2.3 & 0.5 & 3.0 & 1.1 \\
\hline \multicolumn{14}{|l|}{ Energy } \\
\hline 1 & 66.3 & 21.3 & 14.1 & 10.7 & 10.0 & 4.9 & 2.6 & 2.5 & 7.4 & 2.1 & 0.5 & 2.9 & 1.0 \\
\hline 2 & 64.9 & 21.2 & 13.6 & 10.3 & 9.3 & 4.7 & 2.4 & 2.4 & 7.2 & 2.3 & 0.5 & 2.9 & 1.1 \\
\hline \multicolumn{14}{|l|}{ Protein $\times$ Energy } \\
\hline Protein $_{0} \times$ Energy $_{1}$ & 65.3 & 22.6 & 12.5 & 10.2 & 9.4 & 4.6 & 2.5 & 2.4 & 7.2 & 2.2 & 0.5 & 2.7 & 1.0 \\
\hline Protein $_{0} \times$ Energy $_{2}$ & 63.7 & 20.9 & 13.9 & 9.9 & 8.8 & 4.4 & 2.3 & 2.3 & 7.1 & 2.1 & 0.4 & 2.9 & 1.0 \\
\hline Protein $_{1} \times$ Energy $_{1}$ & 67.4 & 20.0 & 15.8 & 11.2 & 10.5 & 5.3 & 2.6 & 2.6 & 7.6 & 2.0 & 0.5 & 3.1 & 0.9 \\
\hline Protein $_{1} \times$ Energy $_{2}$ & 66.0 & 21.5 & 13.2 & 10.8 & 9.9 & 5.0 & 2.4 & 2.5 & 7.4 & 2.6 & 0.5 & 2.9 & 1.2 \\
\hline SEM $^{15}$ & 0.92 & 0.50 & 0.64 & 0.18 & 0.25 & 0.13 & 0.06 & 0.04 & 0.13 & 0.12 & 0.02 & 0.11 & 0.09 \\
\hline \multicolumn{14}{|l|}{ Significance ${ }^{16}$} \\
\hline Protein & NS & NS & NS & $\star \star$ & NS & NS & NS & * & NS & NS & NS & NS & NS \\
\hline Energy & NS & NS & NS & NS & NS & NS & NS & NS & NS & NS & NS & NS & NS \\
\hline Protein $\times$ Energy & NS & NS & NS & NS & NS & NS & NS & NS & NS & NS & NS & NS & NS \\
\hline \multicolumn{14}{|c|}{${ }^{1}$ Protein 0 = Low, 1 = High, Energy 1 = Low, 2 = High; } \\
\hline \multicolumn{14}{|c|}{$\begin{array}{l}{ }^{2} \mathrm{DP}=\text { Dressing percentage, }{ }^{3} \mathrm{BRW}=\text { Breast weight, }{ }^{4} \mathrm{BKW}=\text { Back weight, }{ }^{5} \mathrm{TW}=\text { Thigh weight, }{ }^{6} \mathrm{DW}=\mathrm{Drumstick} \text { weight, }{ }^{7} \mathrm{SW}=\mathrm{Shank} \text { weight }(\mathrm{g}) \text {, } \\
{ }^{8} \mathrm{HW}=\text { Head weight }(\mathrm{g}),{ }^{9} \mathrm{NW}=\text { Neck weight, }{ }^{10} \mathrm{WW}=\text { Wing weight, }{ }^{11} \mathrm{LW}=\mathrm{Liver} \text { weight, }{ }^{12} \mathrm{GW}=\mathrm{Gizzard} \text { weight, }{ }^{13} \mathrm{PW}=\mathrm{Proventriculus} \text { weight, } \\
{ }^{14} \mathrm{AFW}=\text { Abdominal fat weight; }\end{array}$} \\
\hline \multicolumn{14}{|c|}{${ }^{15}$ SEM = Standard error of the means; } \\
\hline
\end{tabular}

\section{Cardio-pulmonary morphometry}

The sources of dietary protein and the levels of metabolizable energy had no main or interaction effects $(p>0.05)$ on cardio-pulmonary morphometry of the experimental birds. The RV:TV remained within standard range $(<0.25)$ indicating no symptoms of cardiac dysfunctions (Table 5). 
Table 5

Cardio-pulmonary morphometry of the broiler birds fed diet supplemented with two sources of dietary protein and two different levels of metabolizable energy slaughtered at 35th day

\begin{tabular}{|c|c|c|c|c|c|c|c|c|c|c|}
\hline \multirow[t]{2}{*}{ Treatment factors ${ }^{1}$} & \multicolumn{10}{|c|}{ Cardio-pulmonary morphometry } \\
\hline & $\mathrm{HW}^{2}$ & $\mathrm{HWL}^{3}$ & $\mathrm{LW}^{4}$ & $\mathrm{LWL}^{5}$ & $\mathrm{RV}^{6}$ & $\mathbf{L V}^{7}$ & $\mathrm{RV}: \mathrm{TV}^{\mathbf{8}}$ & $\mathrm{RD}^{9}$ & LD $^{10}$ & RD: LD $^{11}$ \\
\hline \multicolumn{11}{|l|}{ Protein } \\
\hline 0 & 9.69 & 0.50 & 12.6 & 0.64 & 0.54 & 1.82 & 0.23 & 0.28 & 1.08 & 0.21 \\
\hline 1 & 8.99 & 0.49 & 10.6 & 0.57 & 0.51 & 1.79 & 0.22 & 0.28 & 1.08 & 0.21 \\
\hline \multicolumn{11}{|l|}{ Energy } \\
\hline 1 & 9.15 & 0.49 & 11.6 & 0.63 & 0.51 & 1.81 & 0.22 & 0.28 & 1.05 & 0.21 \\
\hline 2 & 9.53 & 0.49 & 11.6 & 0.59 & 0.54 & 1.80 & 0.23 & 0.28 & 1.10 & 0.21 \\
\hline \multicolumn{11}{|l|}{ Protein $\times$ Energy } \\
\hline Protein $_{0} \times$ Energy $_{1}$ & 9.91 & 0.52 & 12.3 & 0.64 & 0.55 & 1.91 & 0.22 & 0.29 & 1.08 & 0.21 \\
\hline Protein $_{0} \times$ Energy $_{2}$ & 9.47 & 0.48 & 13.0 & 0.64 & 0.52 & 1.73 & 0.24 & 0.28 & 1.08 & 0.20 \\
\hline Protein $_{1} \times$ Energy $_{1}$ & 8.39 & 0.47 & 11.0 & 0.61 & 0.47 & 1.70 & 0.22 & 0.26 & 1.03 & 0.20 \\
\hline Protein $_{1} \times$ Energy $_{2}$ & 9.59 & 0.51 & 10.3 & 0.54 & 0.55 & 1.88 & 0.23 & 0.29 & 1.13 & 0.21 \\
\hline SEM $^{12}$ & 0.27 & 0.01 & 1.05 & 0.05 & 0.02 & 0.05 & 0.01 & 0.01 & 0.03 & 0.00 \\
\hline \multicolumn{11}{|l|}{ Significance $e^{13}$} \\
\hline Protein & NS & NS & NS & NS & NS & NS & NS & NS & NS & NS \\
\hline Energy & NS & NS & NS & NS & NS & NS & NS & NS & NS & NS \\
\hline Protein $\times$ Energy & NS & NS & NS & NS & NS & NS & NS & NS & NS & NS \\
\hline \multicolumn{11}{|c|}{${ }^{1}$ Protein $0=$ Low, 1 = High, Energy $1=$ Low, 2 = High; } \\
\hline \multicolumn{11}{|c|}{$\begin{array}{l}{ }^{2} \mathrm{HW}=\text { Heart weight }(\mathrm{g}),{ }^{3} \mathrm{HLW}=\text { Heart weight }\left(\% \text { live weight), }{ }^{4} \mathrm{LW}=\mathrm{Lung} \text { weight }(\mathrm{g}),{ }^{5} \mathrm{LLW}=\text { Lung weight }(\% \text { live weight }),{ }^{6} \mathrm{RV}=\mathrm{Right}\right. \\
\text { ventricular weight }(\mathrm{g}),{ }^{7} \mathrm{LV}=\mathrm{Left} \text { ventricular weight }(\mathrm{g}),{ }^{8} \mathrm{RV}: \mathrm{TV}=\text { Weight of right ventricle: total ventricle, }{ }^{9} \mathrm{RD}=\mathrm{Right} \text { ventricular diameter } \\
(\mathrm{mm}),{ }^{10} \mathrm{LD}=\text { Left ventricular diameter }(\mathrm{mm}),{ }^{11} \mathrm{RD}: \mathrm{LD}=\text { Diameter of right ventricle: total ventricle; }\end{array}$} \\
\hline \multicolumn{11}{|c|}{${ }^{12} \mathrm{SEM}=$ Standard error of the means; } \\
\hline
\end{tabular}

\section{Gut morphology}

The sources of protein and the levels of dietary energy had no $(p<0.05)$ effect on gut morphology of the broiler birds $($ Table 6$)$. 
Table 6

Gut morphology of the broiler birds fed diet supplemented with two sources of dietary protein and two different levels of metabolizable energy slaughtered at 35th day

\begin{tabular}{|c|c|c|c|c|c|c|c|c|c|c|c|}
\hline \multirow{3}{*}{$\begin{array}{l}\text { Treatment factors }{ }^{1} \\
\mathrm{~L}\end{array}$} & \multicolumn{11}{|c|}{ Gut morphology2 } \\
\hline & \multirow{2}{*}{$\begin{array}{l}\text { PW } \\
W\end{array}$} & \multirow{2}{*}{$\begin{array}{l}\text { GW } \\
\text { D }\end{array}$} & \multicolumn{3}{|c|}{ Duodenum } & \multicolumn{3}{|c|}{ Jejunum } & \multicolumn{3}{|l|}{ Ileum } \\
\hline & & & L & W & D & L & W & D & L & W & D \\
\hline \multicolumn{12}{|l|}{ Protein } \\
\hline 0 & 11.29 & 60.16 & 39.69 & 16.05 & 3.19 & 93.06 & 53.73 & 2.95 & 60.17 & 25.71 & 2.95 \\
\hline 1 & 12.08 & 59.22 & 35.36 & 14.37 & 3.21 & 95.76 & 48.73 & 2.97 & 64.88 & 29.36 & 3.07 \\
\hline Energy & 0.00 & 0.00 & 0.00 & 0.00 & 0.00 & 0.00 & 0.00 & 0.00 & 0.00 & 0.00 & 0.00 \\
\hline 1 & 11.88 & 59.03 & 36.16 & 14.65 & 2.90 & 91.31 & 51.34 & 2.84 & 57.04 & 23.60 & 2.87 \\
\hline 2 & 11.09 & 57.15 & 39.69 & 16.78 & 3.16 & 91.35 & 53.26 & 3.03 & 69.38 & 32.62 & 3.18 \\
\hline Protein $\times$ Energy & 0.00 & 0.00 & 0.00 & 0.00 & 0.00 & 0.00 & 0.00 & 0.00 & 0.00 & 0.00 & 0.00 \\
\hline Protein $_{0} \times$ Energy $_{1}$ & 11.88 & 56.96 & 38.51 & 15.93 & 3.29 & 92.91 & 56.22 & 2.82 & 55.86 & 24.86 & 2.97 \\
\hline Protein $_{0} \times$ Energy $_{2}$ & 11.88 & 60.35 & 35.28 & 14.28 & 3.18 & 97.47 & 45.07 & 2.37 & 51.74 & 17.20 & 2.62 \\
\hline Protein $_{1} \times$ Energy $_{1}$ & 13.07 & 59.22 & 37.04 & 15.27 & 2.94 & 93.48 & 53.21 & 3.10 & 72.91 & 41.10 & 3.49 \\
\hline Protein $_{1} \times$ Energy $_{2}$ & 11.29 & 58.09 & 33.75 & 13.55 & 3.53 & 96.33 & 47.91 & 3.44 & 69.97 & 29.80 & 3.08 \\
\hline $\mathrm{SEM}^{3}$ & 12.47 & 50.20 & 37.63 & 12.69 & 2.35 & 87.21 & 46.01 & 2.82 & 72.32 & 30.64 & 3.20 \\
\hline \multicolumn{12}{|l|}{ Significance ${ }^{4}$} \\
\hline Protein & NS & NS & NS & NS & NS & NS & NS & NS & NS & NS & NS \\
\hline Energy & NS & NS & NS & NS & NS & NS & NS & NS & NS & NS & NS \\
\hline Protein $\times$ Energy & NS & NS & NS & NS & NS & NS & NS & NS & NS & NS & NS \\
\hline \multicolumn{12}{|c|}{${ }^{1}$ Protein $0=$ Low, 1 = High, Energy 1 = Low, $2=$ High; } \\
\hline \multicolumn{12}{|c|}{${ }^{2} \mathrm{~L}=$ Length $(\mathrm{cm}), \mathrm{W}=$ Width $(\mathrm{mm}), \mathrm{D}=$ Diameter $(\mathrm{mm})$; } \\
\hline \multicolumn{12}{|c|}{${ }^{3} \mathrm{SEM}=$ Standard error of the means; } \\
\hline${ }^{4} \mathrm{NS}=$ Non-significa & $(p>0.0$ & & & & & & & & & & \\
\hline
\end{tabular}


Table 7

Fatty acid profile of the breast meat (Pectoralis major) of the broiler birds fed diet supplemented with two sources of dietary protein and two different levels of metabolizable energy

\begin{tabular}{|c|c|c|c|c|c|c|c|c|c|c|c|c|}
\hline \multirow[t]{3}{*}{ Fatty acids } & \multicolumn{2}{|c|}{ Protein } & \multicolumn{2}{|l|}{ Energy } & \multicolumn{4}{|c|}{ Protein $\times$ Energy ${ }^{1}$} & \multirow[t]{3}{*}{ SEM } & \multicolumn{3}{|c|}{ Significance } \\
\hline & \multirow[t]{2}{*}{0} & \multirow[t]{2}{*}{1} & \multirow[t]{2}{*}{1} & \multirow[t]{2}{*}{2} & \multirow{2}{*}{$\begin{array}{l}\text { Protein }_{0} \\
\times \\
\text { Energy }_{1}\end{array}$} & \multirow{2}{*}{$\begin{array}{l}\text { Protein }_{0} \\
\times \\
\text { Energy }_{2}\end{array}$} & \multirow{2}{*}{$\begin{array}{l}\text { Protein }_{1} \\
\times \\
\text { Energy }_{1}\end{array}$} & \multirow{2}{*}{$\begin{array}{l}\text { Protein }_{1} \\
\times \\
\text { Energy }_{2}\end{array}$} & & \multirow[t]{2}{*}{ Protein } & \multirow[t]{2}{*}{ Energy } & \multirow{2}{*}{$\begin{array}{l}\text { Protein } \\
x \\
\text { Energy }\end{array}$} \\
\hline & & & & & & & & & & & & \\
\hline C4:0 & 0.00 & 0.42 & 0.21 & 0.21 & 0.00 & 0.00 & 0.42 & 0.43 & 0.08 & $\star \star \star ~$ & NS & NS \\
\hline C10:0 & 0.00 & 4.40 & 2.23 & 2.17 & 0.00 & 0.00 & 4.46 & 4.33 & 0.83 & $\star \star \star ~$ & NS & NS \\
\hline C14:0 & 0.45 & 0.43 & 0.40 & 0.49 & 0.39 & 0.52 & 0.40 & 0.47 & 0.02 & NS & $\star \star \star ~$ & $\star \star \star *$ \\
\hline C15:0 & 1.48 & 3.25 & 2.25 & 2.48 & 1.16 & 1.80 & 3.35 & 3.15 & 0.35 & $\star \star \star$ & NS & $\star \star \star$ \\
\hline C16:0 & 22.26 & 19.60 & 20.41 & 21.45 & 21.25 & 23.28 & 19.58 & 19.62 & 0.58 & $\star \star \star$ & NS & $\star \star \star$ \\
\hline C16:1, $\omega-7$ & 1.95 & 3.09 & 3.34 & 1.69 & 3.52 & 0.38 & 3.16 & 3.01 & 0.47 & $\star \star \star ~$ & $\star \star \star ~$ & $\star \star \star$ \\
\hline C17:0 & 1.93 & 0.37 & 0.38 & 1.92 & 0.33 & 3.53 & 0.44 & 0.31 & 0.52 & $\star \star$ & $\star \star$ & 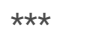 \\
\hline $\mathrm{C} 17: 1, c-10, \omega-7$ & 0.57 & 1.22 & 0.93 & 0.87 & 0.53 & 0.62 & 1.33 & 1.12 & 0.13 & $\star \star \star$ & $\star \star \star$ & $\star \star \star$ \\
\hline C18:0 & 6.95 & 4.65 & 6.19 & 5.40 & 6.10 & 7.79 & 6.29 & 3.01 & 0.66 & NS & $\star \star \star$ & $\star \star \star$ \\
\hline$C 18: 1, t-9, \omega-9$ & 14.23 & 0.58 & 0.47 & 14.34 & 0.26 & 28.21 & 0.69 & 0.48 & 4.54 & * & NS & $\star \star \star$ \\
\hline$C 18: 1, c-9, \omega-9$ & 16.46 & 24.20 & 28.43 & 12.22 & 32.92 & 0.00 & 23.95 & 24.45 & 4.64 & $\star \star \star \star$ & NS & $\star \star \star$ \\
\hline $18: 2, c-9,12, \omega-6$ & 27.21 & 26.34 & 25.76 & 27.80 & 26.26 & 28.17 & 25.26 & 27.43 & 0.49 & NS & * & NS \\
\hline $\begin{array}{l}18: 3, c-6,9,12 \\
\omega-6\end{array}$ & 0.27 & 0.74 & 0.59 & 0.42 & 0.54 & 0.00 & 0.65 & 0.84 & 0.12 & $\star \star \star *$ & $\star \star \star \star$ & $\star \star \star$ \\
\hline $\mathrm{C} 20: 1, c-11, \omega-9$ & 0.65 & 0.86 & 0.87 & 0.65 & 0.85 & 0.46 & 0.89 & 0.84 & 0.07 & NS & NS & $\star \star \star$ \\
\hline $\begin{array}{l}\text { C18:3, c-9,12,15, } \\
\omega-3\end{array}$ & 1.29 & 2.04 & 1.43 & 1.89 & 1.60 & 0.97 & 1.27 & 2.82 & 0.27 & 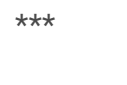 & $\star \star \star$ & $\star \star \star$ \\
\hline $\begin{array}{l}\text { C20:2, c-11,14, } \\
\omega-6\end{array}$ & 0.61 & 0.65 & 0.69 & 0.57 & 0.72 & 0.50 & 0.66 & 0.64 & 0.03 & $\star \star \star$ & NS & $\star \star \star ~$ \\
\hline $\begin{array}{l}\text { C20:3, c-8,11,14, } \\
\omega-6\end{array}$ & 0.37 & 0.92 & 0.83 & 0.45 & 0.73 & 0.00 & 0.93 & 0.91 & 0.14 & $\star \star \star *$ & NS & $\star \star \star ~$ \\
\hline $\begin{array}{l}\text { C20:4, c- } \\
5,8,11,14, \omega-6\end{array}$ & 3.23 & 4.63 & 3.66 & 4.20 & 2.66 & 3.80 & 4.66 & 4.60 & 0.31 & $\star \star \star *$ & NS & $\star \star \star$ \\
\hline $\begin{array}{l}\mathrm{C} 21: 5, c \\
5,8,11,14,17, \omega-3\end{array}$ & 0.12 & 0.00 & 0.12 & 0.00 & 0.24 & 0.00 & 0.00 & 0.00 & 0.04 & $\star \star \star$ & $\star \star \star \star$ & $\star \star \star \star$ \\
\hline C24:1, c-15, $\omega-9$ & 0.00 & 1.16 & 0.59 & 0.57 & 0.00 & 0.00 & 1.17 & 1.15 & 0.22 & $\star \star \star ~$ & * & NS \\
\hline $\begin{array}{l}C 22: 6, c- \\
4,7,10,13,16,19 \\
\omega-3\end{array}$ & 0.00 & 0.48 & 0.26 & 0.23 & 0.00 & 0.00 & 0.51 & 0.46 & 0.09 & $\star \star \star$ & $\star \star \star$ & $\star \star$ \\
\hline$\sum \omega-3$ & 1.40 & 2.52 & 1.81 & 2.12 & 1.84 & 0.97 & 1.78 & 3.27 & 0.31 & * & 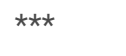 & $\star \star \star \star$ \\
\hline$\sum \omega-6$ & 31.68 & 33.27 & 31.52 & 33.43 & 30.89 & 32.46 & 32.14 & 34.40 & 0.57 & NS & NS & NS \\
\hline$\sum \omega-7$ & 2.52 & 4.30 & 4.26 & 2.56 & 4.05 & 1.00 & 4.48 & 4.13 & 0.53 & $\star \star \star$ & $\star \star \star$ & $\star \star \star$ \\
\hline \multicolumn{13}{|c|}{${ }^{1}$ Protein $0=$ Low, $1=$ High, Energy 1 = Low, 2 = High; } \\
\hline \multicolumn{13}{|c|}{${ }^{2} \sum S F A=$ Sum of saturated fatty acids; } \\
\hline \multicolumn{13}{|c|}{${ }^{3} \sum$ UFA = Sum of unsaturated fatty acids; } \\
\hline \multicolumn{13}{|c|}{${ }^{4} \sum$ MUFA = Sum of mono-unsaturated fatty acids; } \\
\hline
\end{tabular}




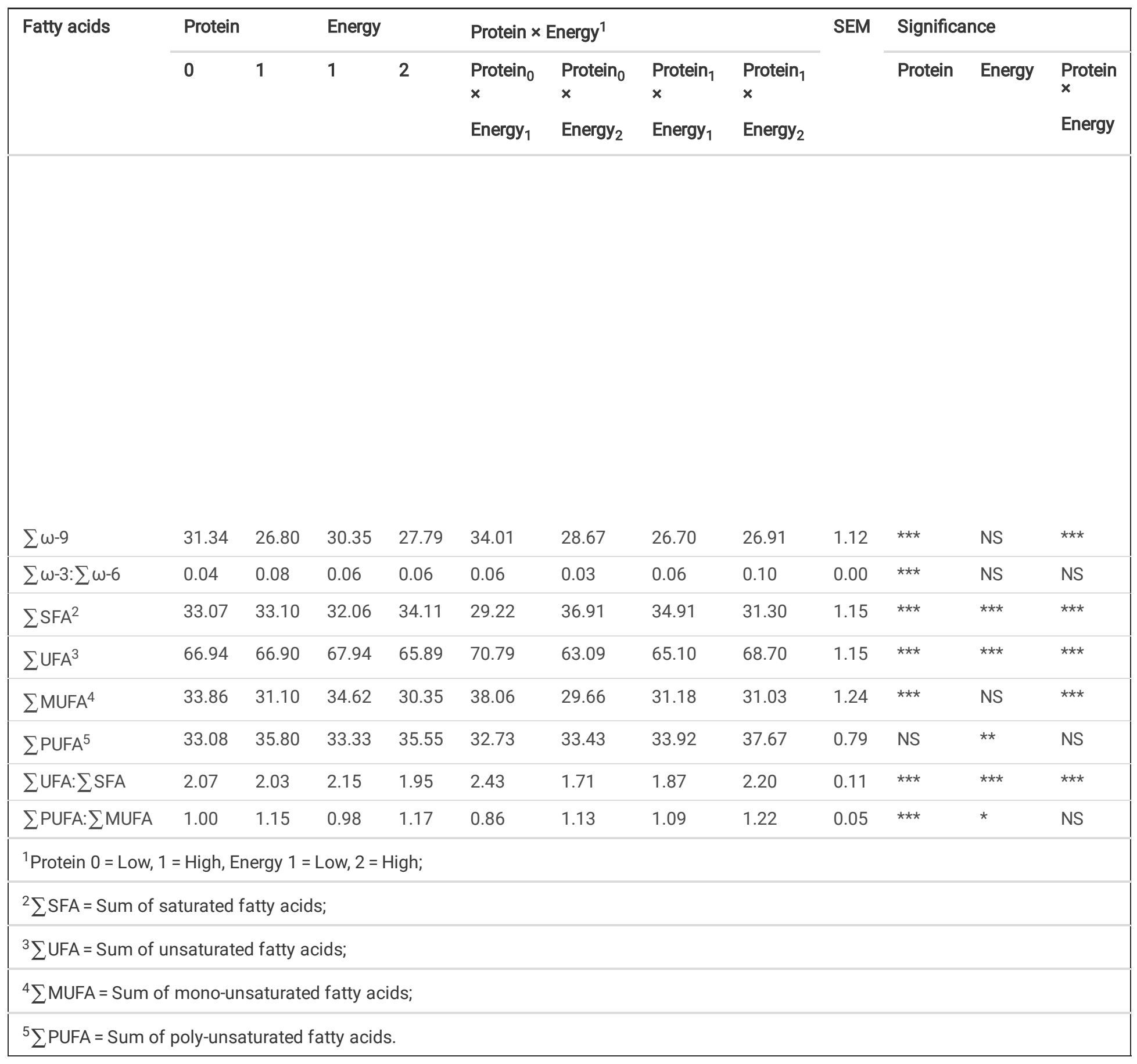

\section{Fatty acid profile}

Replacement of plant protein with fish protein substantially increased $(p<0.001)$ the relative proportions of butyric, decanoic, myristic, pentadecanoic, palmitoleic, cis-10 heptadecanoic, $y$-linolenic, linolenic, cis-11,14 eicosadioenoic, cis-5,8,11,14 eicosatrienoic, nervonic, docosahexaenoic, total $\omega-3, \omega-7$ and the ratio of $\sum \omega-3: \sum \omega-6, \sum$ UFA: $\sum$ SFA and $\sum$ PUFA: $\sum$ MUFA in the breast muscles of the broiler birds.

\section{Humoral immunity}

The sources of dietary protein and the levels of metabolizable energy had no main or interaction effects $(p>0.05)$ on humoral immunity of the broiler birds against Newcastle and Infectious Bronchitis Diseases (Table 8). 
Table 8

Immunity parameters of the broiler birds against Newcastle (ND) and Infectious Bronchitis Disease (IBD) supplemented with two sources of dietary protein and two different levels of metabolizable energy

\begin{tabular}{|c|c|c|c|c|}
\hline \multirow{4}{*}{$\begin{array}{l}\text { Treatment } \\
\text { factors }^{1}\end{array}$} & \multicolumn{4}{|c|}{ Humoral immunity parameters } \\
\hline & \multicolumn{2}{|l|}{ ND } & \multicolumn{2}{|l|}{ IBD } \\
\hline & ND HI titer & ND HI titer & IBD titer & IBD titer \\
\hline & $\begin{array}{l}\text { at 7th } d \text { first } \\
\text { vaccination }\end{array}$ & $\begin{array}{l}\text { at 7th } \mathrm{d} \text { booster } \\
\text { vaccination }\end{array}$ & $\begin{array}{l}\text { at } 7 \text { th } \mathrm{d} \text { first } \\
\text { vaccination }\end{array}$ & $\begin{array}{l}\text { at 7th } \mathrm{d} \text { booster } \\
\text { vaccination }\end{array}$ \\
\hline \multicolumn{5}{|l|}{ Protein } \\
\hline 0 & 24.88 & 24.13 & 0.13 & 0.75 \\
\hline 1 & 25.25 & 24.00 & 0.00 & 0.63 \\
\hline \multicolumn{5}{|l|}{ Energy } \\
\hline 1 & 25.00 & 24.00 & 0.13 & 0.50 \\
\hline 2 & 25.13 & 24.13 & 0.00 & 0.88 \\
\hline \multicolumn{5}{|l|}{ Protein $\times$ Energy } \\
\hline Protein $_{0} \times$ Energy $_{1}$ & 24.75 & 24.00 & 0.25 & 0.50 \\
\hline Protein $_{0} \times$ Energy $_{2}$ & 25.00 & 24.25 & 0.00 & 1.00 \\
\hline Protein $_{1} \times$ Energy $_{1}$ & 25.25 & 24.00 & 0.00 & 0.50 \\
\hline Protein $_{1} \times$ Energy $_{2}$ & 25.25 & 24.00 & 0.00 & 0.75 \\
\hline SEM $^{2}$ & 0.17 & 0.14 & 0.06 & 0.12 \\
\hline \multicolumn{5}{|l|}{ Significance $^{3}$} \\
\hline Protein & NS & NS & NS & NS \\
\hline Energy & NS & NS & NS & NS \\
\hline Protein $\times$ Energy & NS & NS & NS & NS \\
\hline \multicolumn{5}{|c|}{${ }^{1}$ Protein 0 = Low, 1 = High, Energy 1 = Low, 2 = High; } \\
\hline \multicolumn{5}{|c|}{${ }^{2}$ SEM = Standard error of the means; } \\
\hline${ }^{3} \mathrm{NS}=$ Non-significa & $(p>0.05)$. & & & \\
\hline
\end{tabular}

\section{Cost-benefit analysis}

The high energy fish protein diets resulted maximum economic benefit compared with vegetable based low energy diets (Table 9). 
Table 9

Cost-benefit analysis of the broiler birds fed diet supplemented with two different sources of dietary protein and two different levels of metabolizable energy

\begin{tabular}{|c|c|c|c|c|}
\hline \multirow[t]{2}{*}{ Line items } & \multicolumn{4}{|c|}{ Dietary treatments ${ }^{1}$} \\
\hline & LEPP & HEPP & LEAP & HEAP \\
\hline \multicolumn{5}{|l|}{ Cost items $\left(\mathrm{BDT}^{2}\right)$} \\
\hline Final weight & 1.93 & 2.04 & 2.38 & 2.47 \\
\hline Feed efficiency & 1.58 & 1.44 & 1.39 & 1.37 \\
\hline Feed intake/bird & 3.04 & 2.94 & 3.31 & 3.38 \\
\hline Feed cost/kg & 35.98 & 37.87 & 40.75 & 41.64 \\
\hline Total feed cost/bird & 109.47 & 111.26 & 134.84 & 140.86 \\
\hline Day old chick & 65.00 & 65.00 & 65.00 & 65.00 \\
\hline Vaccination & 5.00 & 5.00 & 5.00 & 5.00 \\
\hline Medication & 5.00 & 5.00 & 5.00 & 5.00 \\
\hline Repair of house & 5.00 & 5.00 & 5.00 & 5.00 \\
\hline Feeder/waterer & 5.00 & 5.00 & 5.00 & 5.00 \\
\hline Incandescent light & 5.00 & 5.00 & 5.00 & 5.00 \\
\hline Salary of labor/attendant & 45.00 & 45.00 & 45.00 & 45.00 \\
\hline Depreciation of house/equipment & 5.00 & 5.00 & 5.00 & 5.00 \\
\hline Miscellaneous ${ }^{3}$ & 15.00 & 15.00 & 15.00 & 15.00 \\
\hline Total cost per broiler & 262.97 & 266.26 & 289.84 & 295.86 \\
\hline Total cost per kg broiler & 136.56 & 130.50 & 121.76 & 119.82 \\
\hline \multicolumn{5}{|l|}{ Return items } \\
\hline Market price per kg live broiler & 138.00 & 138.00 & 138.00 & 138.00 \\
\hline Market price per broiler & 265.73 & 281.56 & 328.50 & 340.76 \\
\hline Net profit per live broiler & 2.76 & 15.30 & 38.67 & 44.89 \\
\hline Net profit per kg live broiler & 2.94 & 7.50 & 16.24 & 18.18 \\
\hline \multicolumn{5}{|c|}{${ }^{1}$ LEPP $=$ Low energy plant protein, HEPP = High energy plant protein, LEAP = Low energy animal protein, HEAP = High energy animal protein; } \\
\hline \multicolumn{5}{|l|}{${ }^{1} 1$ USD\$ = 85.00 BDT; } \\
\hline
\end{tabular}

\section{Discussions}

\section{Performance}

In the present study, we observed decreased $(\mathrm{P}<0.001)$ feed intake in the broiler birds due to supplementation of fish protein. The trend appears consistent with a previous study where benefits of the inclusion of fishmeal on feed intake were less evident during earlier stages but later on it was exhibited (Karimi, 2006). The reasoning could be the presence of biogenic amines (Barnes et al., 2001; Karimi, 2006), poor digestible protein content and objectionable odor of the fish meal (Halliwell and Chirico, 1993) which the chicks were unable to utilize at the earlier stages. The result, however, contradicts with the findings of Oduguwa et al. (2021) who reported significantly (P $\leq 0.05)$ higher daily feed intake of the broiler birds supplied animal protein than those of the other treatments. In our study, we ensured normal appearance and smell of the fish meal when subjected to visual appraisal. The actual discrepancies, therefore, could be due to the variations of the levels of 
fish meal used, metabolizable energy and protein contents of the diets although incorporation of even $16.6 \%$ of the sun dried fish offal to the diets of growing RIR chicken did not affect feed intake in a previous study (Tera et al., 2011).

We further observed increased daily gain while birds were offered diets supplemented with fish protein compared with plant protein. The improved palatability of the fish protein, well balanced amino acid profile, higher efficiency of utilization and improved feeding values of the diets supplemented with fish proteins might have contributed to the better weight gain of broiler during the starter and finisher period with the maximum benefit evident at 15-35 d (Memon et al., 2002; Metwally, 2004). It was also reported that this response was dose dependent although Karimi (2006) explained that the further increase of the levels of fish meal beyond optimum growth response was affected by sex and age of the birds (Negesse and Tera, 2010; Melesse et al., 2013). In another study, it was claimed that the fishmeal could be used at different levels up to $8 \%$ in broiler diets without adversely affecting weight gain (Awoniyi et al., 2003). Santana-Delgado et al. (2008) further demonstrated that there were no differences in the weight gain of the broiler chicken providing diet with either soybean meal or fishmeal. Similar results were reported elsewhere (Johnson et al., 1985).

We observed improved feed efficiency (FE) for the fish protein supplemented diets compared with the plant protein. The result is consistent with Hossain et al. (2012) who explained that the better protein digestibility of the fish protein fortified diets as well as increased efficiency of utilization of energy available in fish proteins were responsible for improved FE (Ali et al., 2001; Alali et al., 2011). This response, however, may not always be consistent with all the fish by-products used for feed formulation since the sources of protein may vary in property, i.e., the protein quality, digestibility, biological value, amino acid profile, physical and chemical properties (Sing and Panda, 1992). These characteristics of individual protein source may affect performance of the birds. However, several researchers reported that the major factor limiting the use of vegetable proteins in practical diet is the existence of naturally occurring deleterious factors including non-starch polysaccharides, tannins and trypsin inhibitors which have adverse effects on nutrient digestibility and absorption (Gatel, 1994; Smits and Annison, 1996). Saxena et al. (1962) reported that the unavailability of amino acids due to presence of anti-nutritional factors was considered a major factor in explaining the poor feed efficiency of the chicks fed diets containing soybean meal. Accordingly, despite being iso-caloric and iso-nitrogenous, better overall performance of the broiler birds in fish protein supplemented diets compared with soybean meal in our study is likely.

\section{Carcass, cardio-pulmonary morphometry and gut morphology}

We observed no changes in the carcass yield, breast meat yield, thigh yield, abdominal fat, liver weight, and heart weight for the sources of dietary protein and energy. It implies that the dietary sources of protein and energy did not alter the yield of carcass and the amount of its associated abdominal fat. Closely similar results were reported in the previous studies (Fanimo et al., 1996; Al-Marzooqi et al., 2010) where size of the liver, gizzard, heart and spleen did not differ significantly between the dietary treatments. The reasoning was that the adequate levels of essential amino acids in both the diets, particularly lysine and methionine used for protein accretion in body and a constant ME:CP ratio was maintained across all the dietary treatments (Si et al., 2001; Baker et al., 2002). Similarly, Hidalgo et al. (2004) also reported no differences in carcass yield, breast meat yield, and abdominal fat pad in broilers fed low CP diets with a constant ME:CP ratio. Dozier and Moran (2001) reported that feeding broiler birds with diets formulated to contain suboptimum levels of ME and CP impaired the amount and yield of carcass components. Contrastingly, Mikulec et al. (2003) reported that the addition of fish protein supplements enhanced the higher values for breast, thigh and drumstick.

\section{Humoral immunity}

In our study, we failed to elucidate the influence of the sources of protein and the levels of metabolizable energy on humoral immunity of the broiler birds. Fish meal contains plasma ceruloplasmin which is an indicator of acute phase inflammation in chicken associated with production or release of inflammatory cytokine (Chamanza et al., 1999). Thus, the results of the present study suggested that the dietary fish meal probably contained anti-inflammatory factors. The eicosapentaenoic acid (EPA) and docosahexaenoic acid (DHA) of fish meal and fish oil can prevent cardiovascular diseases and altogether affect the vascular and haemo-static systems, the brain, retina and other body tissues (Stansby et al., 1965; Visentainer et al., 2000). Usually, materials of sea foods and fish meals contain greater amount of carnitine and taurine. Thus, it was hypothesized that the carnitine and taurine particularly rich in fish protein sources were concerned in the better immune performance observed in chicks fed diet containing fish meal during immune stimulation. Previous studies reported that the dietary carnitine increased the plasma IGF concentration (Kita et al., 2002) and immune response. Mast et al. (2000) suggested that the carnitine enhances the host-defense system. However, effects of dietary carnitine and taurine on broiler performances have not yet reached substantial agreement in other studies (Dunnington et al., 1996; Buyse et al., 2001; Zhan et al., 2006).

We deserved more studies to clarify the physiological nature of the dietary supplemented carnitine and taurine as factors stimulating growth and immune response in fish meal. It was hypothesized that a dietary protein source with higher biological value will result a lower urea and uric acid concentrations in blood serum compared to those with lower biological values (Bandegan et al., 2010). Dietary supplementation with more than $3.3 \mathrm{~g} \mathrm{EPA}+\mathrm{DHA} / 100 \mathrm{~kg} \mathrm{BW}$ daily (and in some studies up to $20.7 \mathrm{~g}$ EPA + DHA/100 kg BW) has been reported to decrease tumour 
necrosis factor-a (TNF-a), interleukin (IL)-1, IL-2, IL-6 and interferon (IFN)-c by mononuclear cell (Early, 1993). Accordingly, it was reported that the fish meal high in n-3 fatty acids, when fed to poultry, can increase the n-3 content in the bird's flesh, thus making this tissue another source of n-3 fatty acids in the human diets (Calder, 2001). Many researchers have demonstrated that the n-3 PUFA has anti-inflammatory properties that benefit the immune system, with particular effectiveness against asthma and rheumatic arthritis (Gerster, 1995; Calder, 2001). Since such direct effects against Newcastle and Infectious Bursal diseases are scant, therefore, similar humoral immune response from fish meal might be anticipated in our study based on ND and IBD titer values.

\section{Fatty acid profile}

It was reported that the fish meal high in n-3 fatty acids when fed to poultry increased the $\omega-3$ fatty acid contents in the muscle of the broiler birds which made those tissues another source of $\omega-3$ fatty acids for the human diets (Early, 1993). Ponnampalam et al. (2002) further reported that the long-chain $\omega-3$ fatty acid contents $(20: 5 n-3,22: 5 n-3$ and 22:6n-3) in the longissimus thoracis muscle were substantially higher with fish meal. Accordingly, the fish oils available in the fish meal not only increase the long chain $\omega-3$ fatty acids in the meat, but also improve the $\omega-6$ : $\omega-3$ ratio (Phetteplace and Watkins, 1989). In the present study we obtained substantially high levels of total $\omega-3$ fatty acids and the ratio of $\sum \omega-3: \sum \omega-6, \sum$ UFA: $\sum$ SFA and $\sum$ PUFA: $\sum$ MUFA in the Pectoralis major muscle of the broiler birds fed diet supplemented with blended fish protein which are fully aligned with previous studies.

\section{Conclusion}

Fishmeal supplemented high energy diet improves weight gain, feed efficiency and meat quality of broiler by increasing $\sum \omega-3$ and $\sum \omega-7$ fatty acids as well as the ratio of $\sum \omega-3: \sum \omega-6, \sum$ UFA: $\sum$ SFA and $\sum$ PUFA: $\sum$ MUFA in the breast muscles of the broiler birds.

\section{Declarations}

\section{Funding}

The Ministry of Science and Technology, Bangladesh (Grant No. BS-285).

\section{Conflicts of interest/Competing interests}

None.

\section{Availability of data and materials}

All the data used in the manuscript exclusively belongs to the mentioned authors.

\section{Code availability}

None.

\section{Author's contribution}

Dr. Md. Emran Hossain conceived the study, procured research grant, led the research team, analyzed data, interpreted the results and finalized the draft. Dr. Nasima Akter conducted the animal trial, ran the immunization program, dressed the carcass and collected data. Dr. Sonnet Podder executed the cardio-pulmonary morphometry. Dr. Karabi Barua prepared the initial draft. Dr. Ahasanul Hoque provided additional insights. All authors read and approved the final manuscript.

\section{Ethics approval}

The entire experimental protocol was approved by the animal welfare law in Bangladesh (Memo No. CVASU/Dir(R\&E)EC/2021/244(3/2).

\section{Consent for publication}

Yes.

\section{Consent to participate}

Yes.

\section{Acknowledgement}


The Ministry of Science and Technology, Bangladesh for providing fund.

\section{References}

1. Al-Marzooqi, W., Al-Farsi, M. A., Kadim, I. T., Mahgoub, O., and Goddard, J. S. 2010. The effect of feeding different levels of sardine fish silage on broiler performance, meat quality and sensory characteristics under closed and open-sided housing systems. Asian-Australasian Journal of Animal Sciences, 23: 1614-1625.

2. Alali, W. Q., Hofacre, C. L., Mathis, G. F., and Batal, A. B. 2011. Effect of Plant-based Protein Meal Use in Poultry Feed on Colonization and Shedding of Salmonella Heidelberg in Broiler Birds. Agriculture Food and Analytical Bacteriology Journal, 1: 45-53.

3. Ali, M. E., Rashid, M. A., and Trainer, M. H. K. 2001. Replacement of Fish Meal by Oyster Meat Meal in Broiler Ration. Journal of Biological Sciences, 1: 660-662.

4. AOAC. 2019. Official methods of analysis of the AOAC (Association of the Official Agricultural Chemists) International, $21^{\text {st }}$ edn., Rockville, Maryland, USA.

5. Awoniyi, T. A. M., Aletor, V. A., and Aina, J. M. 2003. Performance of broiler - Chickens fed on maggot meal in place of fishmeal. International Journal of Poultry Science, 2: 271-274.

6. Baker, D. H., Batal, A. B., Parr, T. M., Augspurger, N. R., and Parsons, C. M. 2002. Ideal ratio (relative to lysine) of tryptophan, threonine, isoleucine, and valine for chicks during the second and third weeks posthatch. Poultry Science, 81: 485-494.

7. Bandegan, A., Kiarie, E., Payne, R. L., Crow, G. H., Guenter, W., and Nyachoti, C. M. 2010. Standardized ileal amino acid digestibility in dryextruded expelled soybean meal, extruded canola seed-pea, feather meal, and poultry by-product meal for broiler chickens. Poultry Science, 89: 2626-2633.

8. Barlow, S. M., and Windsor, M. L. 1984. Fishery by-products, International Association of Fish Meal Manufacturers, Potters Bar, Hertfordshire, UK.

9. Barnes, D. M., Kirby, Y. K., and Oliver, K. G. 2001. Effects of biogenic amines on growth and the incidence of proventricular lesions in broiler chickens. Poultry Science, 80: 906-911.

10. Beski, S. S. M., Swick, R. A., and lji, P. A. 2015. Specialized protein products in broiler chicken nutrition: A review. Animal Nutrition, 1: 47-53.

11. El Boushy, A. R. Y., and van der Poel, A. F. B. 2000. Palatability and Feed Intake Regulations, In: Handbook of Poultry Feed from Waste processing and use, 2nd Edn., Springer Science, Berlin, Germany, pp. 348-397.

12. Buyse, J., Janssens, G. P. J., and Decuypere, E. 2001. The effects of dietary L-carnitine supplementation on the performance, organ weights and circulating hormone and metabolite concentrations of broiler chickens reared under a normal or low temperature schedule. British Poultry Science, 42: 230-241.

13. Calder, P. C. 2001. N-3 polyunsaturated fatty acids, inflammation and immunity: Pouring oil on troubled waters or another fishy tale? Nutrition Research, 21: 309-341.

14. Chamanza, R., Van Veen, L., Tivapasi, M. T., and Toussaint, M. J. M. 1999. Acute phase proteins in the domestic fowl. World's Poultry Science Journal, 55: 67-71.

15. Cho, J. H., and Kim, I. H. 2011. Fish meal - nutritive value. Journal of Animal Physiology and Animal Nutrition, 95: 685-692.

16. Cromwell, G. L. 1999. Soybean Meal - The "Gold Standard”, The Farmer's Pride, KPPA News, Vol. 11, No. 20, pp. : $9-11$.

17. Cromwell, D. 2008. Soybean Meal-An Exceptional Protein Source, Technical Report, pp. : 1-15.

18. Dozier, W. A., and Moran, E. T. 2001. Response of early- and late-developing broilers to nutritionally adequate and restrictive feeding regimens during the summer. Journal of Applied Poultry Research, 10: 92-98.

19. Duncan, D. B. 1955. Multiple Range and Multiple F Tests. Biometrics, 11: 1.

20. Dunnington, E. A., Siegel, P. B., and Stewart, K. K. 1996. Effects of Dietary Taurine on Growth and Escherichia coli Resistance in Chickens. Poultry Science, 75: 1330-1333.

21. Early, J. C. 1993. Fish processing technology. Fisheries Research, 16: 363-365.

22. Fanimo, A. O., Mudama, E., Umukoro, T. O., and Oduguwa, O. O. 1996. Substitution of shrimp waste meal for fish meal in broiler chicken rations. Tropical Agriculture, 73: 201-205.

23. Folch, J., Lees, M., and Sloane Stanley, G. H. 1957. A simple method for the isolation and purification of total lipides from animal tissues. The Journal of biological chemistry, 226: 497-509.

24. Gatel, F. 1994. Protein quality of legume seeds for non-ruminant animals: a literature review. Animal Feed Science and Technology, 45: 317-348.

25. Gerster, H. 1995. The use of n-3 PUFAs (fish oil) in enteral nutrition. International Journal for Vitamin and Nutrition Research, 65: 3-20. 
26. Gous, R. M. 2007. Methodologies for modelling energy and amino acid responses in poultry. Revista Brasileira de Zootecnia, 36: $263-275$.

27. Halliwell, B., and Chirico, S. 1993. Lipid peroxidation: its mechanism, measurement, and significance. The American journal of clinical nutrition, 57: 715S-725S.

28. Hidalgo, M. A., Dozier, W. A., Davis, A. J., and Gordont, R. W. 2004. Live performance and meat yield responses of broilers to progressive concentrations of dietary energy maintained at a constant metabolizable energy-to-crude protein ratio. Journal of Applied Poultry Research, 13: 319-327.

29. Hossain, M. A., Islam, A. F., and lji, P. A. 2012. Energy utilization and performance of broiler chickens raised on diets with vegetable proteins or conventional feeds. Asian Journal of Poultry Science, 6: 117-128.

30. Hossain, M. A., Islam, A. F., and lji, P. A. 2013. Growth responses, excreta quality, nutrient digestibility, bone development and meat yield traits of broiler chickens fed vegetable or animal protein diets. South African Journal of Animal Sciences, 43: 208-218.

31. Johnson, R. J., Brown, N., Eason, P., and Sumner, J. 1985. The nutritional quality of two types of fish silage for broiler chickens. Journal of the Science of Food and Agriculture, 36: 1051-1056.

32. Jones, R. 1984. A standard method of dissection of poultry for carcass analysis, Technical Bulletin No. 222, West of Scotland Agricultural College, Scotland. : Technical Bulletin. 222.

33. Karimi, A. 2006. The effects of varying fishmeal inclusion levels (\%) on performance of broiler chicks. International Journal of Poultry Science, 5: 255-258.

34. Kita, K., Kato, S., Yaman, M. A., Okumura, J., and Yokota, H. 2002. Dietary L-carnitine increases plasma insulin-like growth factor-I concentration in chicks fed a diet with adequate dietary protein level. British Poultry Science, 43: 117-121.

35. Kolacz, R., Korniewicz, A., Dobrzañski, Z., Korniewicz, D., and Usydus, Z. 2003. Effects of dietary modified fish meal [MFM] on physicochemical and sensory properties of pig loin. Electronic Journal of Polish Agricultural Universities, 2: 1-9.

36. Leeson, S., and Summers, J. D. 2009. Commercial Poultry Nutrition, 3rd Edn., Nottingham University Press, Nottingham NG7 2RD, UK, pp. 413.

37. Mast, J., Buyse, J., and Goddeeris, B. M. 2000. Dietary L-carnitine supplementation increases antigen-specific immunoglobulin G production in broiler chickens. British Journal of Nutrition, 83: 161-166.

38. Melesse, A., Getye, Y., Berihun, K., and Banerjee, S. 2013. Effect of feeding graded levels of Moringa stenopetala leaf meal on growth performance, carcass traits and some serum biochemical parameters of Koekoek chickens. Livestock Science, 157: 498-505.

39. Memon, A., Ansari, N. N., Solangil, A. A., and Memon, G. 2002. Effect of blood meal on the growth and carcass yield of broilers. Pakistan Veterinary Journal, 1: 105-107.

40. Metwally, M. A. 2004. Evaluation and the optimum use of feather meal as a non-conventional feedstuff for poultry diets. Egyptian Poultry Science Journal, 24: 41-62.

41. Mikulec, Ž., Mas, N., Šerman, V., Dumanovski, F., Mašek, T., Horvat, Ž., and Sušić, V. 2003. Mogućnost primjene pripravka" Protein Gold" kao zamjene za riblje brašno u tovu pilića. Krmiva: Časopis o hranidbi životinja, proizvodnji i tehnologiji krme, 45: $201-207$.

42. Mills, S., Stanton, C., Lane, J. A., Smith, G. J., and Ross, R. P. 2019. Precision nutrition and the microbiome, part I: Current state of the science. Nutrients, 11: 923.

43. Negesse, T., and Tera, A. 2010. Effects of feeding different levels of cooked and sun dried fish offal on carcass traits of growing Rhode Island Red chicks. Tropical Animal Health and Production, 42: 45-54.

44. Oduguwa, O. O., Fanimo, A. O., and Jegede, A. V. 2021. Effect of enzyme supplementation on the utilization of shrimp waste meal based diets by broiler chicken. Nigerian Journal of Animal Production, 31: 167-173.

45. Phetteplace, H. W., and Watkins, B. A. 1989. Effects of various n-3 lipid sources on fatty acid compositions in chicken tissues. Journal of Food Composition and Analysis, 2: 104-117.

46. Pike, I. H. 1999. Health Benefits From Feeding Fish Oil and Fish Meal. Ifoma Technical Bulletin, 28: 3-6.

47. Ponnampalam, E. N., Sinclair, A. J., Hosking, B. J., and Egan, A. R. 2002. Effects of dietary lipid type on muscle fatty acid composition, carcass leanness, and meat toughness in lambs. Journal of Animal Science, 80: 628-636.

48. Santana-Delgado, H., Avila, E., and Sotelo, A. 2008. Preparation of silage from Spanish mackerel (Scomberomorus maculatus) and its evaluation in broiler diets. Animal Feed Science and Technology, 141: 129-140.

49. Saxena, H. C., Jensen, L. S., and McGinnis, J. 1962. Failure of amino acid supplementation to completely overcome the growth depression effect of raw soybean meal in chicks. The Journal of nutrition, 77: 259-263.

50. Scanes, C. 2010. Poultry Science-Growing as an International. Poultry Science, 88: 195-196.

51. Si, J., Fritte, C. A., Burnham, D. J., and Waldroup, P. W. 2001. Relationship of dietary lysine level to the concentration of all essential amino acids in broiler diets. Poultry Science, 80: 1472-1479. 
52. Sifri, M. 1995. Nutrient Requirements of Poultry. Poultry Science, 74: 224.

53. Sing, K., and Panda, B. 1992. Poultry nutrition, Kallyani publishers, 4779/23, Ansari Road, Darya Ganj, New Delhi-110002, India.

54. Smits, C. H. M., and Annison, G. 1996. Non-starch plant polysaccharides in broiler nutrition - Towards a physiologically valid approach to their determination. World's Poultry Science Journal, 52: 217-221.

55. Stansby, M. E., Schlenk, H., and Gruger, E. H. 1965. Fatty Acid Composition of Fish Oils. Nutrition Reviews, $23: 51-52$.

56. Takahashi, K., Akiba, Y., and Matsushita, K. 2004. Effect of Substitution of Fish Meal with Soybean Meal on Growth Performances and Excreta Moisture Contents During Immunological Stimulation in Male Broiler Chicks. Journal of Poultry Science, 41: $241-247$.

57. Tera, A., Negesse, T., and Melesse, A. 2011. Effect of rate of inclusion of fishmeal prepared by cooking and sun drying of fish offal on feed intake and nutrient retention of growing Rhode Island Red chicks. SINET: Ethiopian Journal of Science, 31: $151-156$.

58. Visentainer, J. V., Carvalho, P. de O., Ikegaki, M., and Park, Y. K. 2000. Concentração de ácido eicosapentaenóico (EPA) e ácido docosahexaenóico (DHA) em peixes marinhos da costa brasileira. Ciência e Tecnologia de Alimentos, 20: 90-93.

59. Yasothai, R. 2016. Antinutritional Factors in Soybean Meal and Its Deactivation. International Journal of Science, Environment, 5: 37933797.

60. Zhan, X. A., Li, J. X., Xu, Z. R., and Zhao, R. Q. 2006. Effects of methionine and betaine supplementation on growth performance, carcase composition and metabolism of lipids in male broilers. British Poultry Science, 47: 576-580. 